\title{
Globalisation and union opposition to technological change
}

\author{
Kjell Erik Lommerud ${ }^{\mathrm{a}, *}$, Frode Meland ${ }^{\mathrm{b}}$, Odd Rune Straume ${ }^{\mathrm{b}}$ \\ ${ }^{a}$ Department of Economics, University of Bergen, Herman Fossgt. 6, N-5007 Bergen, Norway \\ ${ }^{\mathrm{b}}$ Department of Economics and Stein Rokkan Centre for Social Studies, University of Bergen, Norway
}

Received 15 September 2003; received in revised form 12 December 2004; accepted 3 March 2005

\begin{abstract}
Trade unions have a rational incentive to oppose the adoption of labour-saving technology when labour demand is inelastic and unions care much for employment relative to wages. Trade liberalisation typically increases trade union technology opposition. These conclusions are reached in a model of unionised international duopoly with two-way trade. We also find that the incentive for technology opposition is stronger in the more technologically advanced country and in the country with the larger home market, complementing earlier explanations for technological catch-up and leapfrogging.

(C) 2005 Elsevier B.V. All rights reserved.
\end{abstract}

Keywords: Trade liberalisation; Technology adoption; International unionised oligopoly

JEL classification: F12; F16; 033; J51; L13

\section{Introduction}

Is technological progress friend or foe of ordinary workers? If one adopts a long-term perspective, the answer is obvious. However, with a shorter time horizon the question

\footnotetext{
* Corresponding author. Tel.: +47 55589209; fax: +47 55589210.

E-mail addresses: kjell-erik.lommerud@econ.uib.no (K.E. Lommerud), frode.meland@econ.uib.no (F. Meland), odd.straume@econ.uib.no (O.R. Straume). 
becomes trickier. Better technology could make possible higher wages and better work conditions, but the labour-saving potential of technological improvement could also spell job losses and wage cuts. The final outcome for workers will depend crucially on the particularities of the situation. In history, the perhaps most famous example of technology resistance is the Luddite revolts in England 1811-1812. ${ }^{1}$ Framework knitters and weavers broke the new labour-saving machinery in their industries until harsh use of capital punishment subdued the riots. Even though the Luddite campaign and similar incidents during early British industrialisation were largely futile, the Luddite position appears rational enough. To quote Duvall (1969): "Most people in 1811 and 1812 found it difficult to appreciate the value of new machinery economizing labour at a time when goods were a glut upon the market and when there was, in any case a surplus of labour available."

Questions about technology and the labour market are obviously not only of historical interest. A prominent example of modern Luddism is the way printers' unions in many countries managed to postpone the introduction of new technology for what actually amounted to decades. This was mainly achieved by forcefully (ab)using strict demarcation rules describing which tasks members of different unions could or could not perform. An overview of the history of printers' unions technology opposition in the UK-where unions' control of the publishing industry did not begin to crumble until the mid-1980scan be found in Mowatt and Cox (2001).

The printers' unions example may be an extreme one, but in today's world of globalisation and rapid technological progress, the adoption of new technologies and accompanying workplace reforms are high on the industrial relations agenda in many countries, and the rate of technology adoption is likely to be significantly affected by labour market institutions, including trade unions. In a recent empirical study, Gust and Marquez (2004) find that regulations affecting labour market practices are important impediments to the adoption of IT technology, and that differences in labour market regulations play an important role in explaining the recent divergence in productivity growth rates between the US and Europe. Of course, the more restrictive labour market regulations in many European countries are to a large extent reflections of the traditional stronghold of trade unions, and unions also play an active role in issues related to workplace reform in most of these countries. In a study of employee participation in company restructuring in 16 European countries, Jørgensen and Navrbjerg (2001) demonstrate in great detail how trade unions are heavily involved in, and sometimes strongly opposed to, restructuring and workplace changes, including the introduction of new technology. In many cases, employee influence on technological change is also legally protected.

Union resistance to the introduction of new technology is not only a European phenomenon, though. This is often a hot issue even in the US, where trade unions are generally weaker. One example is the extended conflict in the latter half of the 1990s between the United Autoworkers Union (UAW) and the major US carmakers, in particular General Motors, over various labour-saving workplace reforms, such as the

\footnotetext{
${ }^{1}$ The movement was named after 'General' Ned Ludd, but it is historically unclear if this was the instigator of the revolt, an alias used by several of the leaders, or simply an imaginary hero.
} 
introduction of 'design-for-manufacturing' (DFM), which resulted in a number of plant strikes. ${ }^{2,3}$ Perhaps the most striking recent example of 'modern Luddism' in the US is the industrial action taken by West Coast dockworkers in 2002 to prevent the introduction of new technology that enabled automated port operations. After a heated period of strikes and lock-outs, the ports were finally re-opened due to a court injunction sought by President Bush. ${ }^{4}$

The process of globalisation and increased international competition is arguably associated with an increased rate of workplace reform-some of which are driven by rapid technological progress-in many industries, which makes the relationship between globalisation and industrial relations an important and often hotly debated issue. The purpose of our paper is to make a somewhat narrower contribution to this very broad issue by providing a theoretical analysis of rational Luddism under globalisation.

It is probably no coincidence that the original Luddite movement arose when it did. The years 1811-1812 were miserable ones for British industry, one chief reason being that Napoleon blockaded British exports to the continent. ${ }^{5}$ Blockades of this type are surely less likely now than under Napoleon, but harsher competition from abroad could perhaps trigger union opposition to technological change in much the same way? Or would workers be eager to give their companies a head start in international competition, so that union resistance to change is weakened? Attempting to disentangle questions as these, we employ a model of unionised international oligopoly, where trade costs of various sorts occur when goods are shipped from one market to the other. Globalisation is taken to mean that these trade costs are reduced, so that each national market is more exposed to foreign competition, but at the same time it is easier also for domestic firms to sell goods abroad.

Our main finding is that globalisation tends to increase the likelihood that workers oppose new technology, provided that the industry in question is characterised by two-way trade, and given that relative market sizes are not too unequal. Under these circumstances, increased competition from abroad-due to globalisation-is counteracted by easier access to foreign markets, causing total labour demand to increase. This contributes to making

\footnotetext{
${ }^{2}$ See McAlinden (1997).

${ }^{3}$ In another example from the automotive industry, Lansbury et al. (2002) couple the bankruptcy of Kia Motors with slow adoption of new technology, and hint that union resistance might have played a role. The Korean auto industry was built up using relatively labour-intensive Fordist mass production in a time when military rule kept wages down. When Kia tried to switch to Toyota-style lean production, unions had become more powerful, and the attempts had mixed success. In the economic slump during the Asian financial crisis in 1997, Kia went bankrupt and was in the end taken over by Hyundai. Of course, if union opposition is indeed to be blamed for the demise of Kia, it can hardly be called rational Luddism, at least not ex post rational, but it nevertheless serves as an example of how trade unions can successfully (in the narrower sense) prevent or postpone the adoption of new technology.

${ }^{4}$ See Greenhouse (2002).

5 As an aside, it is noteworthy that times were harsh not only for workers, but for many industrialists, too. When Prime Minister Spencer Perceval, who introduced capital punishment for machine breaking in the Framebreaking Act, was shot dead in the lobby of the House of Commons in 1812, the assassin was not a Luddite rebel, but a bankrupt businessman.
} 
labour demand more inelastic, which can be shown to increase the likelihood of job losses if new labour-saving technology is introduced. Consequently, the likelihood that a trade union will oppose the implementation of such technology increases. If technology opposition hurts the interests of future generations of workers, this problem is aggravated by globalisation.

We also ask what market size and relative technological position might imply for technology opposition by unionised workers. We find that technology opposition is larger in a country with a large home market and with a technological advantage. This points to an explanation why technological laggards sometimes catch-up with more advanced countries or even overtake them, to complement other explanations that has been offered for this phenomenon.

On a more general level, our paper relates to a vast literature that deals with labour market effects of technological change, where much recent contributions centre on the question if the widening wage dispersion especially in the US and the UK can be traced back to new technology. ${ }^{6}$ The narrower question about the relationship between trade unions and technological innovation-which is more closely related to the present studyhas also received much attention. ${ }^{7}$ Theoretical studies often focus on hold-up problems: the fact that unions are powerful may discourage investments both in productive capacity and in technology. 8,9

The opposite question, how technological change affects the bargaining position of workers, is analysed less frequently. The contribution by Dowrick and Spencer (1994)which serves as an important building block for the present analysis-is the theoretical economics paper that tackle the Luddite question most directly: they ask when the introduction of labour-saving technology hurts unionised workers, so that Luddite technology opposition would be rational? They study a situation where, at the same time, firms have market power in output markets and workers have market power in the labour market. Rational Luddism occurs in their model when labour demand is relatively inelastic. Also, the more a union values jobs rather than wage increases, the more likely becomes rational opposition to technology changes. ${ }^{10}$ The present paper can thus be seen as both an application and an extension of the Dowrick-Spencer paper, where we place the analysis in the context of international trade and globalisation, and analyse how trade liberalisation, relative market size and technological advantages affect union opposition to technological change.

\footnotetext{
${ }^{6}$ Acemoglu (2002) offers an interesting overview.

7 See Menezes-Filho and Van Reenen (2003) for a survey both of theoretical positions and empirical evidence.

${ }^{8}$ Grout (1983) and Manning (1987) were seminal contributions. Ulph and Ulph (2001) explicitly introduce innovation in a unionised context, and compare bargaining structures that to different degrees open up for holdups by workers after technological investment is sunk.

9 Some authors point out that unions can be beneficial for technology adoption. For example, Agell and Lommerud (1993) and Moene and Wallerstein (1997) show how some unions' taste for wage compression can 'push' the economy towards structural change and modernisation.

${ }^{10}$ The Dowrick-Spencer model analyses technology and wage and employment changes within various given structures of labour market institutions. Acemoglu et al. (2001) develop a model where skill-biased technical change leads to deunionisation, because the coalition among skilled and unskilled workers is undermined. Deunionisation removes the wage compression imposed by unions and therefore amplifies the direct effect that skill-biased technical change has on wage inequality.
} 
Our work is also related to theoretical research on the consequences of globalisation for unionised oligopolies. Key references are Naylor $(1998,1999) .{ }^{11}$ Naylor uses a framework that has many similarities to our model, most importantly the combination of international unionised oligopoly and monopoly union wage setting. Naylor stresses that globalisation need not be hurtful for organised labour. Harsher competition can in fact imply that both employment rises and wages go up if the industry is characterised by two-way trade. ${ }^{12}$ However, technology is not an issue in Naylor's analysis, so although the present model shares many traits with Naylor's framework, we analyse a distinctly different question by studying workers' incentives to sabotage the application of new technology. Our results complement Naylor's research by stressing that, although globalisation may be beneficial for unionised workers for a given production technology, it may also make workers more vulnerable to technological change.

Finally, it should be underlined that the results from this kind of unionised oligopoly model fit rather poorly with historical Luddism. Our model shares with Naylor the prediction that harsher competition in an international oligopoly under fairly mild assumptions will imply increased labour demand. Globalisation can lead to more technology opposition precisely because labour demand goes up. As already underlined, the original Luddite revolts broke out in a period of very low labour demand, which does not tally well with this aspect of the model. The models of Dowrick-Spencer and ourselves investigate when a union representing all workers will oppose technology. A revolt, on the other hand, can be instigated by a subset of workers, for example by the frustrated workers who have already lost their jobs, so the question of when the introduction of new technology leads to massive protests from some of the workers, is a slightly different one from the one we attempt to answer here. ${ }^{13}$

\section{Model}

There are two firms, each producing a differentiated product. Firm 1 is located in country 1 and firm 2 in country 2 . Competition is assumed to be Cournot, but it can easily be shown that the qualitative results do not change if we instead analysed the case of Bertrand competition. ${ }^{14}$ We adopt the segmented market hypothesis, where firms

\footnotetext{
${ }^{11}$ See also, for example, Lommerud et al. (2003), Lommerud et al. (2005, in press), Meland (2002), Straume (2002, 2003), Neary (2002), Andersen and Sørensen (2003), Piperakis et al. (2003) and Munch and Skaksen (2002). Staiger (1988) shares Naylor's prediction that the union wage premium may rise with intensified international competition, but in a different model framework.

${ }^{12}$ Naylor assumes products to be homogenous and discusses Cournot competition. Gürtzgen (2002) obtain similar results for the Bertrand differentiated products case.

13 Moreover, workers in Britain 200 years ago were living close to subsistence level: then, in a downswing, workers might give extreme priority not to lose their job. The present study uses a Stone-Geary union utility function, which is convenient for tractability reasons and very often used in this type of analysis. However, it is not fully general, and the possibility that the employment priority in union utility rises very sharply in a downturn is therefore ruled out by assumption.

${ }^{14}$ An analysis of the Bertrand case is available in the Working Paper version, available at http://skylla.wzberlin.de/pdf/2003/ii03-18.pdf.
} 
maximise profits by choosing sales in each market (country) separately. ${ }^{15}$ Output produced in country $i$ (by firm $i$ ) and sold in market $j$ is denoted $q_{i j}$, so that total sales for firm $i-$ denoted $q_{i}$-is given by $q_{i}=\sum_{j=1}^{2} q_{i j}$. Demand is assumed to be linear ${ }^{16}$, with the inverse demand functions for goods 1 and 2 in market $j$ given by

$$
p_{1 j}=a-\frac{1}{s_{j}}\left(q_{1 j}+b q_{2 j}\right),
$$

and

$$
p_{2 j}=a-\frac{1}{s_{j}}\left(q_{2 j}+b q_{1 j}\right),
$$

where $s_{j}>0$ is a measure of the size of market $j$, and $b \in(0,1)$ is a measure of product differentiation.

Both firms operate under constant returns to scale with labour as the only input. Let $n_{i}$ denote the amount of labour employed in the production of good $i$. The following technology applies:

$$
q_{i}=\phi_{i} n_{i}
$$

where $\phi_{i}>0$ is a firm-specific technology parameter.

There are two cost components: each unit of labour employed by firm $i$ is paid a wage rate $w_{i}$. In addition, there is a trade cost, $t$, associated with shipping one unit of a good between the two countries. In principle, these trade costs can include both tariff and nontariff cost components. We further assume that the labour market in country 1 is unionised, whereas the firm located in country 2 can recruit workers from a competitive labour market at a wage rate $w_{2}=\bar{w} \cdot{ }^{17,18}$ For simplicity, we assume that the outside wage (that can be earned outside the oligopoly industry) for workers in country 1 also equals $\bar{w}$. To save notation, we set $w_{1}=w$.

We adopt the monopoly union model, where the trade union in country 1 freely chooses the wage at a stage prior to the Cournot subgame. ${ }^{19}$ Union preferences are characterised by the following Stone-Geary-type utility function:

$$
U=(w-\bar{w})^{\theta} n_{1},
$$

\footnotetext{
${ }^{15}$ The segmented markets oligopoly model was made popular by Brander and Krugman (1983). Neary (2003) presents a general equilibrium picture of international oligopoly with segmented markets.

${ }^{16}$ This assumption can be considerably loosened while the main results are still maintained. See footnote 29 for a further discussion.

${ }^{17}$ Early contributions to unionised oligopoly models include Brander and Spencer (1988), Dowrick (1989) and De Fraja (1993).

${ }^{18}$ Lommerud et al. (2003) and Straume (2003) are other examples of international oligopoly models with asymmetric union power across countries. Naylor $(1998,1999)$ and Haaland and Wooton (2003) study situations where unions are equally powerful in all countries.

${ }^{19}$ For tractability reasons, the combination of linear Cournot oligopoly and monopoly unions is commonplace in the literature on unionised international oligopoly. The monopoly union can be seen as that special case of the right-to-manage model where unions have all the bargaining power. We use this model as a simple representation of a situation where wage bargaining is inefficient because workers have a larger degree of control over wage setting than over how employment is determined. However, in Section 6 we use numerical simulations to analyse the effect of wage bargaining.
} 
where $\theta>0$ represents the relative importance of wages over employment for the trade union. Note that $\theta=1$ corresponds to a rent-maximising union.

The source of the labour-saving technological change is taken to be exogenous, and we follow Dowrick and Spencer (1994) by analysing the effect of a marginal increase in the technology parameter $\phi_{i}$. We consider the following three-stage game:

- Stage 1: The union determines whether or not it will accept the implementation of a labour-saving innovation.

- Stage 2: The wage rate in country 1 is unilaterally set by the trade union.

- Stage 3: Employment in each firm is determined by the firms' simultaneous and independent choices of optimal output levels for each market.

Stage 1 is not chosen for its realism. Rather, we want to study what the union would have decided about technology if it had been given the chance. The domestic union may well be in a position where it can sabotage introduction of labour-saving innovations. Firms may anticipate that unions will not necessarily concede to the changes in manning rules, remuneration systems and the like that new technology requires. Firms may then in various ways be able to bribe workers to facilitate the introduction of innovations, but technological change will nevertheless be more costly and we should expect to see less of it. In other cases, unions and workers have no influence over technology choice, for example when an upstart firm builds a new plant ahead of hiring any workers. The present analysis is then not a positive analysis of technology adoption, but simply asks if workers benefit or not from the technological changes that do take place, something that in turn could constitute an important part of a normative analysis of technology policy.

We solve by backwards induction. The next section discusses the production game at stage 3 .

\section{Product market equilibrium}

For given wages and technologies, each firm maximises profits by choosing the optimal level of sales for each market. The optimisation problem facing firm 1 is thus

$$
\max _{q_{11}, q_{12}}\left[\pi_{1}=\left(p_{11}-\frac{w}{\phi_{1}}\right) q_{11}+\left(p_{12}-\frac{w}{\phi_{1}}-t\right) q_{12}\right] .
$$

The first-order conditions are given by

$$
q_{11}=\frac{a s_{1}-b q_{21}-s_{1} \frac{w}{\phi_{1}}}{2}
$$

and

$$
q_{12}=\frac{(a-t) s_{2}-b q_{22}-s_{2} \frac{w}{\phi_{1}}}{2} .
$$


Making similar calculations for firm 2 and assuming that all quantities are positive, we get the following equilibrium quantities:

$$
q_{11}=s_{1} \frac{a(2-b)+b t+b \frac{\bar{w}}{\phi_{2}}-2 \frac{w}{\phi_{1}}}{4-b^{2}},
$$

and

$$
q_{12}=s_{2} \frac{a(2-b)-2 t+b \frac{\bar{w}}{\phi_{2}}-2 \frac{w}{\phi_{1}}}{4-b^{2}} .
$$

Obviously, the problem facing firm 2 is similar, so that the equilibrium quantities $q_{21}$ and $q_{22}$ are of a similar structure as the expressions given above.

In an international duopoly, three different trade regimes are logically possible: two-way trade, one-way trade or autarky. Two-way trade means that both duopolists export into the neighbouring market, so this is intra-industry or cross-hauling trade of the same good. One-way trade means that one of the duopolists export, but not the other. Arguing slightly outside the model, if there are several oligopolies in an economy, we will expect a country to export the goods from some oligopolies, but import the goods from others, so then the actual result in the one-way trade case is inter-industry trade.

Our focus here, however, will be on two-way trade. Lommerud et al. (2003) discuss in detail, in a related set-up, under what trade costs what regime will arise in equilibrium. ${ }^{20,21}$ Two-way trade generally occurs for relatively 'low' trade costs. When we study trade liberalisation with two-way trade, this means that what we have in mind are economies that are rather well integrated to begin with but where trade costs are lowered even more. There always exists a range of the model parameters for which the equilibrium entails two-way trade. To see this, note that as the trade costs approach zero, the firms either produce for both or none of the markets (the effective production costs for the two markets are the same). Consequently, the union will-for such very low trade costs-never want to set a wage so high that the unionised firm does not export. Similarly, the foreign firm cannot be induced to stop shipping goods into the union home country either. It could be that the unionised economy had a large technological lead, but if it is not profitable for the laggard to export at almost zero trade cost, the laggard will not find it profitable to operate in his home country either, so we would not have an operative duopoly. In general, a sufficiently low level of trade costs induces two-way trade in equilibrium.

\footnotetext{
${ }^{20}$ Note that even though labour costs will be higher in the unionised country, there may be one-way trade from the unionised to the non-unionised country if the technology of the unionised firm is sufficiently better than that of the non-unionised firm.

${ }^{21}$ See also Naylor (1999) and Straume (2003) for discussions of trade patterns in unionised international oligopolies.
} 
Assuming two-way trade in equilibrium, labour demand by firm 1 is given by

$$
n_{1}(w)=\frac{\left[s_{1}+s_{2}\right]\left[a(2-b)+b \frac{\bar{w}}{\phi_{2}}-2 \frac{w}{\phi_{1}}\right]-t\left(2 s_{2}-s_{1} b\right)}{\phi_{1}\left(4-b^{2}\right)} .
$$

\section{Union wage setting}

The union's wage setting is governed by a trade off between wages and employment. The first-order condition for optimal wage setting, on a general form, is given by

$$
\varepsilon_{1}(w)=\frac{\theta w}{w-\bar{w}},
$$

where $\varepsilon_{1}(w):=-\frac{\partial n_{1}(w)}{\partial w} \frac{w}{n_{1}(w)}$ is the wage elasticity of labour demand for the unionised firm. More inelastic labour demand (lower $\varepsilon_{1}$ ) increases the equilibrium wage. Obviously, the wage will be higher the stronger the union values wages over employment, as represented by $\theta$. Using (10), the equilibrium wage in the two-way trade regime is found to be

$$
w^{*}=\frac{\left[s_{1}+s_{2}\right]\left[\phi_{1} \theta a(2-b)+\bar{w}\left(2+\theta b \frac{\phi_{1}}{\phi_{2}}\right)\right]-\phi_{1} \theta t\left(2 s_{2}-s_{1} b\right)}{2(1+\theta)\left(s_{1}+s_{2}\right)} .
$$

Some comparative statics properties of (12) can be immediately established. Less differentiated products (higher $b$ ) will intensify competition and reduce the union wage level. A contraction (expansion) of demand from the home (export) market will have the same effect, provided that there are positive trade costs. Likewise, an increase in productivity for the foreign firm will also have a negative impact on the union wage. This is all quite intuitive. Our main concern, however, is the effect of a change in the technology parameter of the unionised firm, $\phi_{1}$. This is explored in detail below.

\section{Union opposition to technological change}

This section contains the main building blocks for the subsequent analysis. It is important to emphasise from the outset that the main results from the first part of this Section have already been confirmed by Dowrick and Spencer (1994) under more general assumptions on product demand and union utility. Thus, the main underlying mechanisms of the model generalises beyond the special assumptions of the current paper, which can be viewed as an application of the general model of Dowrick and Spencer in the context of international oligopoly and trade liberalisation. It is nevertheless instructive to recapitulate and elaborate on these underlying effects in our specific context.

We consider an incremental labour-saving innovation in the unionised firm, i.e., a marginal increase in the technology parameter $\phi_{1}$. The effects on equilibrium wages and employment and union utility will be analysed consecutively. 


\subsection{Equilibrium wages}

A labour-saving innovation will cause a wage response from the union insofar as the innovation changes the own-wage elasticity of labour demand. It is useful to decompose the total effect into a slope-of-demand effect and a demand-shifting effect: in general, an increase in $\phi_{1}$ changes both the slope of the labour demand curve and the demand for labour at the pre-innovation wage. Labour demand elasticity is affected through both channels. Starting with the first effect, from (10) we can easily calculate

$$
\frac{\partial}{\partial \phi_{1}}\left(-\frac{\partial n_{1}(w)}{\partial w}\right)=-\frac{4\left(s_{1}+s_{2}\right)}{\phi_{1}^{3}\left(4-b^{2}\right)}<0,
$$

implying that increased labour productivity reduces the wage responsiveness of labour demand. This is very intuitive: if workers are highly productive, an increase in the wage level will have only a moderate impact on the effective wage rate $\left(w / \phi_{1}\right)$. Ceteris paribus, this effect makes labour demand less elastic and pulls in the direction of higher wage claims by the union.

A labour-saving innovation also affects labour demand directly, in two different ways. On the one hand, it reduces the marginal cost of production, $w / \phi_{1}$, which tends to increase the demand for labour. This again provides an incentive for the union to increase wage claims. On the other hand, a labour-saving innovation increases the productivity of each worker, which has the opposite effect on labour demand, since the same production quantity can now be produced using fewer workers. Thus, the overall demand-shifting effect is generally ambiguous. From (10) we can derive

$$
\frac{\partial n_{1}(w)}{\partial \phi_{1}}=\frac{2\left(s_{1}+s_{2}\right) w\left(1-\frac{1}{\varepsilon_{1}(w)}\right)}{\phi_{1}^{3}\left(4-b^{2}\right)},
$$

implying that increased labour productivity causes a reduction (increase) in labour demand if the wage elasticity of labour demand-at the pre-innovation level-is below (above) unity. $^{22}$ If labour demand is inelastic, a small reduction in the marginal cost of production $\left(w / \phi_{1}\right)$ leads to a less than proportionate increase in the demand for effective labour $\left(\phi_{1} n_{1}\right){ }^{23}$ Consequently, the firm does not need the entire existing labour forcewhich is now more efficient-to meet the new demand for effective labour, causing labour demand to fall. Obviously, the opposite result holds true for elastic labour demand.

Although the slope-of-demand effect and the demand-shifting effect may work in opposite directions, the net impact on labour demand is that it becomes less elastic.

\footnotetext{
${ }^{22}$ This result-which generalises beyond linear demand-corresponds to Proposition 1 in Dowrick and Spencer (1994).

${ }^{23}$ Using (3), it is easily shown that the elasticity of labour demand with respect to the wage level is equal to the elasticity of effective labour demand with respect to the effective wage, i.e., $\varepsilon_{1}=-\frac{\partial\left(\phi_{1} n_{1}\right)}{\partial\left(w / \phi_{1}\right)} \frac{\left(w / \phi_{1}\right)}{\left(\phi_{1} n_{1}\right)}$.
} 
Consequently, the union will respond to the implementation of a labour-saving innovation by increasing the wage level. From (12) we find that

$$
\frac{\partial w^{*}}{\partial \phi_{1}}=\theta \frac{\left[a(2-b)+b \frac{\bar{w}}{\phi_{2}}\right]\left[s_{1}+s_{2}\right]-t\left(2 s_{2}-s_{1} b\right)}{2(1+\theta)\left(s_{1}+s_{2}\right)} .
$$

A closer inspection of (15) reveals that $\partial w^{*} / \partial \phi_{1}>0$ for all permissible values of the model parameters. ${ }^{24}$

\subsection{Equilibrium employment}

The total effect of a technological improvement on employment is given by

$$
\frac{\mathrm{d} n_{1}\left(w^{*}\right)}{\mathrm{d} \phi_{1}}=\left.\frac{\partial n_{1}(w)}{\partial \phi_{1}}\right|_{w=w^{*}}+\left.\frac{\partial n_{1}(w)}{\partial w}\right|_{w=w^{*}} \frac{\partial w^{*}}{\partial \phi_{1}} .
$$

From (15) we know that the second term is unambiguously negative. Thus, a net increase in employment as a result of a labour-saving innovation requires that the first term, $\partial n_{1}(w) / \partial \phi_{1}$, is positive, and sufficiently large to dominate the second term. Using (14), this is equivalent to saying that $\varepsilon_{1}$ must be sufficiently larger than 1 . From (10) and (12) we find that $\partial n_{1}\left(w^{*}\right) / \partial \phi_{1}>0$ if

$$
\left(s_{1}+s_{2}\right)\left[\phi_{2} \phi_{1} a(2-b)+\bar{w}\left(b \phi_{1}-4 \phi_{2}\right)\right]<\phi_{2} \phi_{1} t\left(b s_{1}-2 s_{2}\right),
$$

which is true only for a relatively small subset of the valid parameter configurations.

\subsection{Union utility}

Whether or not the trade union will (rationally) resist the introduction of a new labour-saving technology ultimately depends on how union utility is affected. We can derive a simple condition that is independent of specific functional forms. Consider a general-form utility function $U\left[w\left(\phi_{1}\right), n_{1}\left(w\left(\phi_{1}\right), \phi_{1}\right)\right]$. Now, invoking the envelope theorem, the effect of a labour-saving innovation on equilibrium union utility is simply given by

$$
\frac{\mathrm{d} U\left[w^{*}\left(\phi_{1}\right), n_{1}\left(w^{*}\left(\phi_{1}\right), \phi_{1}\right)\right]}{\mathrm{d} \phi_{1}}=\left.\frac{\partial U(\cdot)}{\partial n_{1}} \frac{\partial n_{1}(w)}{\partial \phi_{1}}\right|_{w=w^{*}} .
$$

Thus, the union will endorse the introduction of new technology only if it leads to an increase in labour demand. This follows from the monopoly union assumption. ${ }^{25}$ Since a

\footnotetext{
${ }^{24}$ Using the condition for $q_{12}>0$ in (9), it can easily be verified that $\partial w^{*} / \partial \phi_{1}>0$ under two-way trade.

${ }^{25}$ In Section 6 we analyse how Nash wage bargaining affect the results.
} 
monopoly union is able unilaterally to set the wage it is indifferent to a marginal wage change at the optimal level, and only the labour demand effect matters. From (14), it follows that $\mathrm{d} U / \mathrm{d} \phi_{1}>0$ if and only if labour demand is elastic, i.e., $\varepsilon_{1}>1$.

As long as labour demand elasticity is not constant along the labour demand curve, the demand elasticity at the equilibrium wage level depends indirectly on union preferences. We can therefore express the condition for union opposition to technological change in terms of the preference parameter $\theta$. When labour demand elasticity is increasing in the wage level-which is true for a wide class of demand functions, including the linear specification $^{26}$-a more wage oriented union will choose a wage on a more elastic part of the labour demand curve, and vice versa. It follows that the labour demand response to innovation, $\partial n_{1}(w) / \partial \phi_{1}$, is monotonically increasing in the wage preference parameter $\theta$, which means that there exists a unique critical value $\theta^{*}$, characterised by

$$
\frac{\partial n_{1}\left[w\left(\theta^{*}\right)\right]}{\partial \phi_{1}}=0,
$$

and

$$
\frac{\partial n_{1}\left[w\left(\theta^{*}\right)\right]}{\partial \phi_{1}}<(>) 0 \text { if } \theta<(>) \theta^{*} .
$$

Thus, the condition $\varepsilon_{1}>1$ translates into a condition that the union must be sufficiently wage oriented $\left(\theta>\theta^{*}\right)$ to benefit from the introduction of a labour-saving innovation. In our specific model, inserting equilibrium wages and employment into the union utility function, we derive

$$
\theta^{*}=1-\frac{4 \frac{\bar{w}}{\phi_{1}}\left(s_{1}+s_{2}\right)}{\left[a(2-b)+b \frac{\bar{w}}{\phi_{2}}\right]\left[s_{1}+s_{2}\right]-t\left(2 s_{2}-s_{1} b\right)} .
$$

Since $\theta^{*}<1$, it follows that a rent-maximising union would never oppose technological change. $^{27}$

In the remainder of the analysis we will utilise the specific structure of our model to see how changes in the key parameters of the model affect union attitudes towards technological change. For the union not to try to sabotage productivity-enhancing technological change, the union must be sufficiently wage oriented. In line with this, we adopt the following interpretation of the model: any structural change that increases (reduces) the critical value $\theta^{*}$ is said to increase (reduce) the likelihood of union opposition to technological change. Note that some unions may oppose technological change both before and after some parameter changes, and some unions may be in favour before and after. But if we picture the economy as consisting of many international unionised oligopolies, where the various unions have different preferences over wages and

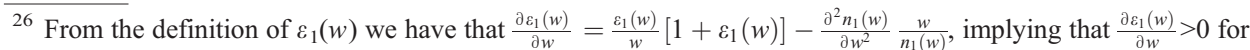
concave, linear and 'not too convex' labour demand functions.

27 This result also generalises beyond the specific assumptions of our model, as demonstrated by Dowrick and Spencer (1994).
} 
employment, an increase in $\theta^{*}$ will induce more unions to go against labour-saving innovation.

\subsection{Globalisation}

The main aim of the paper is to analyse how globalisation-interpreted as a reduction of trade costs between countries-affects union attitude towards labour-saving technological change in oligopolistic industries. ${ }^{28}$ The following result is obtained:

Proposition 1. Globalisation increases the probability of union opposition to technological change if (i) the industry is characterised by two-way trade, and (ii) the domestic market is not too large relative to the foreign market.

Proof. From (17) we find that

$$
\frac{\partial \theta^{*}}{\partial t}=-\frac{4\left(2 s_{2}-s_{1} b\right) \frac{\bar{w}}{\phi_{1}}\left(s_{1}+s_{2}\right)}{\left\{\left[a(2-b)+b \frac{\bar{w}}{\phi_{2}}\right]\left[s_{1}+s_{2}\right]-t\left(2 s_{2}-s_{1} b\right)\right\}^{2}}<(>) 0,
$$

if

$$
s_{1}<(>) \frac{2}{b} s_{2}
$$

The size-difference between markets referred to in Proposition 1 depends crucially on how differentiated the two products are. For very close substitutes, the home market must be less than twice the size of the foreign market. However, for unrelated products $(b \rightarrow 0)$, the above result essentially applies regardless of market sizes.

The intuition behind Proposition 1, which is not straightforward, can ultimately be traced to the effect of trade liberalisation on labour demand, but first we have to do a preliminary round of explanation. Trade liberalisation affects the critical value of $\theta^{*}$ insofar as the effect of technological change on labour demand elasticity is influenced by a reduction of trade costs. From (16) we know that the union will oppose technological change if it reduces labour demand, which, in turn, depends on the wage elasticity of labour demand. More specifically, a labour-saving innovation will reduce (increase) labour demand if $\varepsilon_{1}<(>) 1$ at the pre-innovation equilibrium. Since labour demand elasticity (in equilibrium) is monotonically increasing in $\theta$, it follows that trade liberalisation increases the critical value of $\theta^{*}$ if it makes labour demand less elastic in equilibrium. In more intuitive terms, if trade liberalisation reduces the probability that technological change increases labour demand, then the trade union must be

\footnotetext{
${ }^{28}$ In line with our broad interpretation of trade costs, globalisation should be thought of as any measures taken to reduce the costs of trade, including reduced tariffs, improved quality of infrastructure and reduced bureaucratic barriers to trade.
} 
more wage oriented (i.e., it must operate on a more elastic part of the demand curve) in order to ensure such a positive labour demand response. Indeed, from (12) and (10) we derive

$$
\left.\frac{\partial \varepsilon_{1}(w)}{\partial t}\right|_{w=w^{*}}=\frac{2\left(s_{1}+s_{2}\right) \bar{w}(1+\theta)\left(2 s_{2}-s_{1} b\right)}{\phi\left[\left(a(2-b)-\bar{w}\left(\frac{2}{\phi_{1}}-\frac{b}{\phi_{2}}\right)\right)\left(s_{1}+s_{2}\right)-t\left(2 s_{2}-s_{1} b\right)\right]^{2}} .
$$

We see that the condition for trade liberalisation to reduce labour demand elasticity, and thus the probability of a positive labour demand response of a technological improvement, is precisely $s_{1}<\left(2 s_{2} / b\right)$.

Now, what remains to explain is the relationship between trade liberalisation and labour demand elasticity. Since $t$ does not affect the slope of the labour demand curve, the sign of $\partial \varepsilon_{1}(w) / \partial t$ is determined by the sign of $\partial\left(\frac{w}{n(w)}\right) / \partial t$. In this context, the effect of trade cost reductions through changes in the equilibrium wage is a second-order effect that never dominates the direct effect on labour demand, so trade liberalisation makes labour demand less elastic if it simply increases the total demand for labour. From (10) it is easily found that

$$
\frac{\partial n_{1}(w)}{\partial t}=-\frac{2 s_{2}-s_{1} b}{\phi_{1}\left(4-b^{2}\right)}<(>) 0,
$$

if

$$
s_{1}<(>) \frac{2 s_{2}}{b},
$$

which confirms our intuition. It is important to note that this effect of trade cost reductions on the elasticity of labour demand applies to a much larger class of demand systems than the linear one. ${ }^{29}$

It is less strenuous to understand why trade liberalisation increases labour demand if $s_{1}<\left(2 s_{2} / b\right)$. A reduction of trade costs implies that both firms improve their competitive positions in their respective export markets. Thus, total labour demand will increase if the gain of market share in the export market more than outweighs the loss of market share domestically. Since reduced trade costs increase the degree of competition, and thus total sales, in both markets, total labour demand from the unionised firm will increase unless the domestic market is very large relative to the foreign market. If products are homogeneous, the domestic market must be more than twice as large as the foreign market in order for the unionised firm to reduce its labour demand in response to a reduction of trade costs. ${ }^{30}$

Perhaps the most interesting implication of this result regards social welfare. Proposition 1 suggests that the traditional welfare gains of globalisation-increased

\footnotetext{
${ }^{29}$ Re-writing the labour demand function for the unionised firm on general form, $n_{1}(w, t)$, with $\varepsilon_{1}(w, t):=$ $\frac{\partial n_{1}(w, t)}{\partial w} \frac{w}{n_{1}(w, t)}$ being the corresponding own-wage elasticity, it is easily shown that trade cost reductions make labour demand less elastic if $-\frac{w}{n_{1}(w, t)}\left(\varepsilon_{1}(w, t) \frac{\partial n_{1}(w, t)}{\partial t}+\frac{\partial^{2} n_{1}(w, t)}{\partial w \partial t}\right)<0$. For a linear demand system we have that $\left(\partial^{2} n_{1}(w, t) / \partial w \partial t\right)=0$, so in this case the inequality is satisfied if $\frac{\partial n_{1}(w, t)}{\partial t}<0$. Thus, in general, the analysis applies to demand systems where $\left(\partial^{2} n_{1}(w, t) / \partial w \partial t\right)$ is negative or not 'too positive'.

${ }^{30}$ If products are independent $(b=0)$, there is no deterioration of the firms' competitive position in their respective home markets, and consequently-in this case-labour demand always increases when $t$ decreases.
} 
competition and lower consumer prices-may be modified by increased union opposition to technological change in oligopolistic industries, which may reduce the rate at which new labour-saving innovations are implemented.

It is important to note, though, that the assumption of two-way trade is crucial to the result in Proposition 1. With, for example, one-way trade into the unionised market, trade liberalisation means that the loss of market share for the unionised firm in the domestic market is not compensated by increased export sales. This makes labour demand more elastic, with a corresponding reduction of $\theta^{*}{ }^{31}$

\subsection{Relative market size}

Maintaining the assumption of two-way trade, we proceed by considering how union attitude towards technological change depends on other key parameters of the model. In accordance with our previous analysis, we explain our results by noting the effect of the relevant parameters on labour demand elasticity. If a parametric change makes labour demand less elastic, a labour-saving technological change is more likely to reduce the demand for labour. This, in turn, increases the critical value of $\theta$, above which the union will benefit from such a technological change.

Let us now consider how union attitude towards labour-saving innovations depends on the relative size of the domestic market. We can establish the following result:

Proposition 2. Union opposition to technological change is more likely the larger the domestic market is relative to the foreign market.

Proof. From (17) we have that

$$
\frac{\partial \theta^{*}}{\partial s_{1}}=\frac{4 \frac{\bar{w}}{\phi_{1}} t s_{2}(2+b)}{\left\{\left[a(2-b)+b \frac{\bar{w}}{\phi_{2}}\right]\left[s_{1}+s_{2}\right]-t\left(2 s_{2}-s_{1} b\right)\right\}^{2}}>0
$$

and

$$
\frac{\partial \theta^{*}}{\partial s_{2}}=-\frac{4 \frac{\bar{w}}{\phi_{1}} t s_{1}(2+b)}{\left\{\left[a(2-b)+b \frac{\bar{w}}{\phi_{2}}\right]\left[s_{1}+s_{2}\right]-t\left(2 s_{2}-s_{1} b\right)\right\}^{2}}<0 .
$$

How does an increase in market size-which is equivalent to an increase in the number of consumers residing in the market in question-affect labour demand elasticity for the unionised firm? Once more, it is useful to decompose the total effect into a slope-ofdemand effect and a demand-shifting effect. It is easily shown that an expansion of either market makes labour demand more wage responsive. Since sales increase, a given increase in wages now results in a larger reduction of labour demand. ${ }^{32}$ Ceteris paribus, this makes

\footnotetext{
${ }^{31}$ We refer to the Working Paper version for an analysis of one-way trade. This is available at http://skylla.wzberlin.de/pdf/2003/ii03-18.pdf.

${ }^{32}$ From (10) we find that $\frac{\partial}{\partial s_{1}}\left(-\frac{\partial n_{1}(w)}{\partial w}\right)=\frac{\partial}{\partial s_{2}}\left(-\frac{\partial n_{1}(w)}{\partial w}\right)=\frac{2}{\phi_{1}^{2}\left(4-b^{2}\right)}>0$.
} 
labour demand more elastic. However. the increase in sales due to a market expansion implies that the demand-shifting effect works in the opposite direction, making labour demand less elastic. The size of this effect depends on which market expands. As long as $t>0$, the increase in sales-and thus labour demand-is larger if the domestic market expands. It turns out that the demand-shifting effect dominates the slope-of-demand effect if the market expansion occurs in the domestic market, making labour demand less elastic. Consequently, union opposition to technological change increases. If the foreign market expands, the opposite result applies. Finally, if $t=0$ the two effects exactly cancel, leaving labour demand elasticity unchanged.

\subsection{Technological advantage}

Another key feature of the model is the possibility of a technological gap between the firms in the industry. How will a technological (dis)advantage affect union attitudes towards labour-saving innovations?

Proposition 3. Union opposition to technological change is more (less) likely if the unionised firm has a technological (dis)advantage.

Proof. From (17) it follows that

$$
\frac{\partial \theta^{*}}{\partial \phi_{1}}=\frac{4 \frac{\bar{w}}{\phi_{1}}\left(s_{1}+s_{2}\right)}{\phi_{1}\left[a(2-b)+b \frac{\bar{w}}{\phi_{2}}\right]\left[s_{1}+s_{2}\right]-t\left(2 s_{2}-s_{1} b\right)}>0
$$

(the denominator in the expression for $\partial \theta^{*} / \partial \phi_{1}$, is confirmed positive by applying the condition for $q_{12}>0$ in (9)) and

$$
\frac{\partial \theta^{*}}{\partial \phi_{2}}=-\frac{4\left(\frac{\bar{w}}{\phi_{2}}\right)^{2} b\left(s_{1}+s_{2}\right)^{2}}{\phi_{1}\left\{\left[a(2-b)+b \frac{\bar{w}}{\phi_{2}}\right]\left[s_{1}+s_{2}\right]-t\left(2 s_{2}-s_{1} b\right)\right\}^{2}}<0 .
$$

Consider an increase in labour productivity for firm 1 -interpreted here as a 'technological advantage' for firm 1. We know from the previous discussion that this will make labour demand less elastic, due to the reduced wage responsiveness of labour demand (see (13)). Obtaining a technological advantage will thus increase the likelihood of union opposition towards the introduction of further labour-saving innovations, and make it more difficult to increase the technological advantage. The opposite result applies if the foreign firm gets a technological advantage. An increase in labour productivity for this firm will unambiguously reduce labour demand from the unionised firm, making labour demand from this firm more elastic.

The result in Proposition 3 suggests the presence of a 'catch-up' effect in the introduction of new technology. Due to union opposition to technological change, it may be more difficult to increase, or even sustain, a technological advantage. 


\section{Extensions}

In the analysis so far, we have utilised a quite particular structural set-up with a monopoly trade union in one country only. Here, we first ask whether our results survive if both countries are unionised. Armed with this result, we discuss the possibility of technological catch-up within this framework. Lastly, we look at the situation where wages are subject to bargaining between the firm and the union.

\subsection{Trade unions in both countries}

Let us first investigate the implications of letting also the foreign firm be unionised. Opening for the possibility of different union preferences in the two countries, we assume that the union in country $i$ maximises

$$
U_{i}=\left(w_{i}-\bar{w}\right)^{\theta_{i}}\left(\frac{q_{i i}+q_{i j}}{\phi_{i}}\right), \quad i, j=1,2 ; \quad i \neq j .
$$

We also assume that wages are set simultaneously in the two countries. Setting $\bar{w}=w_{2}$ in the product market equilibrium expressions derived in Section 3 , it is straightforward to derive the wage equilibrium from (19). The equilibrium wage level in country $i$ is given by

$$
w_{i}^{*}=\frac{4 \bar{w} \phi_{j}\left(\theta_{j}+1\right)+2 \theta_{i} \phi_{i}\left(a \phi_{j}(2-b)+b \bar{w}\right)+a \phi_{1} \phi_{2} \Psi-\frac{\phi_{1} \phi_{2} t}{s_{1}+s_{2}} \Omega_{i}}{\phi_{j}\left(4\left(1+\theta_{1}+\theta_{2}\right)+\Psi\right)},
$$

where

$$
\begin{aligned}
\Omega_{i}: & =\theta_{i}\left[s_{j} \theta_{j}\left(4-b^{2}\right)+2\left(2 s_{j}-s_{i} b\right)\right], \\
\Psi: & =\theta_{1} \theta_{2}\left(4-b^{2}\right)>0 .
\end{aligned}
$$

Let the wage equilibrium be denoted by the vector $\mathbf{w}^{*}$. Using the envelope theorem, the effect of a labour-saving innovation on union utility in country $i$ is now given by

$$
\frac{\mathrm{d} U_{i}\left(\mathbf{w}^{*}\right)}{\mathrm{d} \phi_{i}}=\frac{\partial U_{i}\left(\mathbf{w}^{*}\right)}{\partial n_{i}}\left[\frac{\partial n_{i}\left(\mathbf{w}^{*}\right)}{\partial w_{j}} \frac{\partial w_{j}^{*}}{\partial \phi_{i}}+\frac{\partial n_{i}\left(\mathbf{w}^{*}\right)}{\partial \phi_{i}}\right] \quad i, j=1,2 ; \quad i \neq j .
$$

A union's response to a marginal technological improvement is still determined by the labour demand effect, but, comparing with (16) we see that there is now an additional effect through the strategic wage response from the foreign country. This effect is unambiguously negative. A technological innovation in firm $i$ will worsen the competitive position of the rival firm, whose union will respond by lowering the wage. This, in turn, reduces labour demand from firm $i .^{33}$

\footnotetext{
${ }^{33}$ It is straightforward to verify that $\partial n_{i} / \partial w_{j}>0$ and $\partial w_{j} * / \partial \phi_{i}<0$.
} 
The explicit expression for the critical value of $\theta_{i}$, below which firm $i$ 's trade union will oppose technological change, is given by

$$
\theta_{i}^{*}=1-\frac{2\left[4+\theta_{j}\left(4-b^{2}\right)\right] \phi_{j} \bar{w}}{\phi_{i}\left(a \phi_{j}(2-b)\left[2+\theta_{j}(2+b)\right]+2 b \bar{w}-\frac{\phi_{2} t}{s_{1}+s_{2}} \Omega_{i}\right)} .
$$

It is possible to show that the denominator is positive ${ }^{34}$, implying that $\theta_{i}<1$, as before. However, the strategic wage response from the rival union suggests that the critical level of $\theta_{i}$ is higher when both countries are unionised. A comparison of (17) and (22) also confirms that this is the case.

From (22) it is straightforward to verify that our previous results are confirmed, broadly speaking, when both countries are unionised. Globalisation still increases union opposition towards labour-saving innovations, as long as market sizes are not too unequal. In the twounion case, we have that

$$
\frac{\partial \theta_{i}^{*}}{\partial t}<0 \text { iff } s_{j} \theta_{j}\left(4-b^{2}\right)+2\left(2 s_{j}-s_{i} b\right)>0
$$

The underlying mechanisms are the same as in the basic model with one union, and increased union opposition is ultimately related to the demand expanding effect of globalisation. However, the more symmetric cost structure in the industry, compared with the one-union case, means that trade cost reductions now increase labour demand for a larger set of parameter configurations.

\subsection{Technological catch-up and leapfrogging}

Both in industrial organisation (for example, Fudenberg et al., 1983 and Reinganum, 1983) and in the trade literature (for example, Brezis et al., 1993 and Desmet, 2002), researchers have studied models of technology leaders that rationally adopt new technology so late that newcomers overtake them. The present model, with its focus on harder union resistance to technology in the technologically leading nation, complements this line of work. Let us first confirm that Propositions 2 and 3 also apply in the case with two optimising unions. It follows from (22) that

$$
\frac{\partial \theta_{i}^{*}}{\partial s_{i}}>0, \quad \frac{\partial \theta_{i}^{*}}{\partial s_{j}}<0, \quad \frac{\partial \theta_{i}^{*}}{\partial \phi_{i}}>0, \quad \frac{\partial \theta_{i}^{*}}{\partial \phi_{j}}<0
$$

which indeed confirms the results from Propositions 2 and 3 regarding the effects of relative market size and technological (dis)advantages.

\footnotetext{
${ }^{34}$ It is straightforward to verify that the denominator of $\theta_{i} *$ is monotonically increasing in $\theta_{j}$, which means that it takes its lowest value for $\theta_{j}=0$. In this case, $\theta_{i} *$ is equal to $\theta^{*}$ from the one-union case, where we have already shown that the denominator is positive.
} 
Assume that the game described in this paper is re-run over time. In every period new technological opportunities present themselves. Apart from the fact that today's technology choice influences tomorrow's technological level, there are no dynamic linkages in the model, so at every point in time technology leaders will have a weaker incentive to install new technology than technology laggards. A 'weaker incentive' in the sense that the critical value of $\theta_{i}$ is higher will not always lead to differences in action. But with many international oligopolies of the described structure the tendency will be that the leader country is less likely to implement new technology. One could also imagine that the preference parameter of the union $\theta_{i}$ varies over time, so that a lower critical value implies that a union will, in expectation, adopt new technology sooner. This argument holds as long as a country continues to have a technological advantage in an industry, that is, until the laggard has caught up with the leader. However, if the leader also is the bigger country, we can even get that the laggard passes the leader, which is what the term leapfrogging standardly refers to. Moreover, this logic applies regardless of whether a union optimises against a non-unionised country or a country that itself has an optimising union.

\subsection{Nash wage bargaining}

Now we revert to the single union case, and discuss wage bargaining. Retaining the right-to-manage assumption, we consider a standard Nash bargaining model where the bargaining outcome is the wage that maximises the Nash product

$$
N=\pi_{1}^{\alpha} U^{1-\alpha}
$$

where reservation payoffs are set equal to zero, and $\alpha \in(0,1)$ is the relative bargaining strength of the firm. ${ }^{35}$

Straightforward calculations yield equilibrium profits

$$
\pi_{1}=\frac{\left(q_{11}\right)^{2}}{s_{1}}+\frac{\left(q_{12}\right)^{2}}{s_{2}} .
$$

Calculating $\theta^{*}$ becomes much harder in this case, though, as the envelope theorem does not apply. Actually, even finding an analytical solution for the optimum wage turns out to be an insurmountable task when $t>0$. Thus, we are forced to resort to numerical simulations. For this purpose, we have designed a MATLAB program that searches for the value of $\theta^{*} .{ }^{36}$

The general conclusion to be drawn from this exercise is illustrated in Fig. 1, where $\theta^{*}$ is plotted against trade costs for different values of $\alpha$. The parameters used in this specific example are $a=100, b=0.5, \bar{w}=15$ and $s_{1}=s_{2}=\phi_{1}=\phi_{2}=1$, but numerous simulations show that the picture given in Fig. 1 is highly representative for the symmetric cases, i.e., $s_{1}=s_{2}$ and $\phi_{1}=\phi_{2}$.

\footnotetext{
35 Our basic monopoly union model now appears as the special case of $\alpha \rightarrow 0$.

36 The program is available from http://www.econ.uib.no/pub/frode/theta.zip.
} 


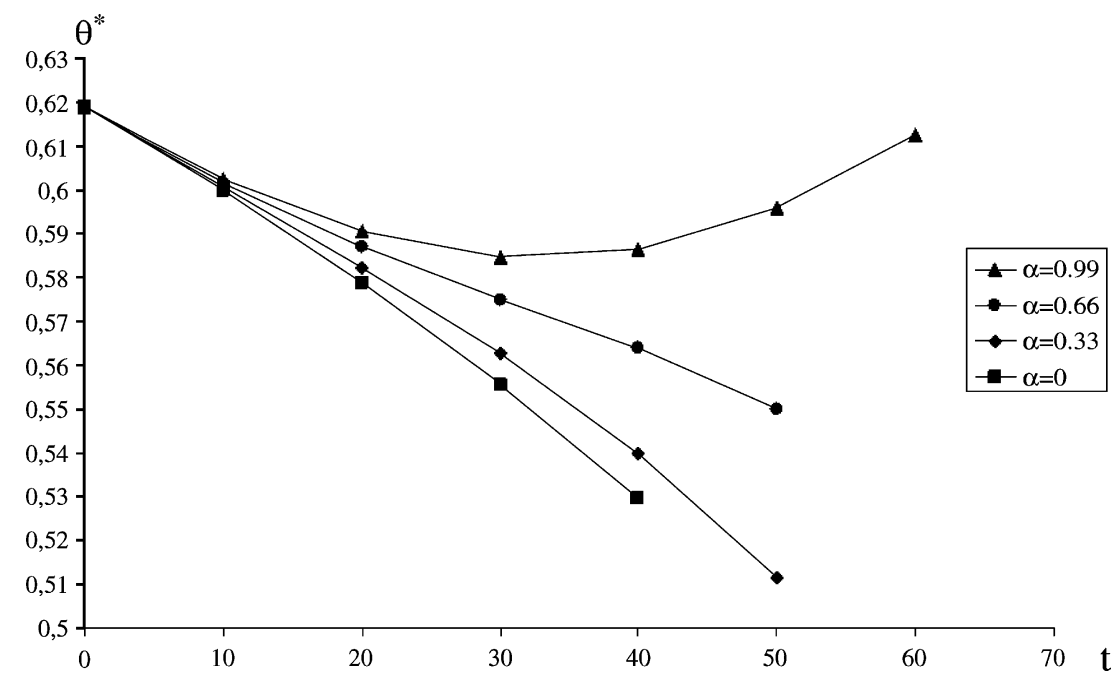

Fig. 1. Globalisation and union opposition under wage bargaining.

With wage bargaining, the effect of a technological change on union utility is given, on general form, by

$$
\frac{\mathrm{d} U\left(w^{*}\right)}{\mathrm{d} \phi_{1}}=\left[\frac{\partial U\left(w^{*}\right)}{\partial w}+\frac{\partial U\left(w^{*}\right)}{\partial n} \frac{\partial n\left(w^{*}\right)}{\partial w}\right] \frac{\partial w^{*}}{\partial \phi_{1}}+\frac{\partial U\left(w^{*}\right)}{\partial n} \frac{\partial n\left(w^{*}\right)}{\partial \phi_{1}} .
$$

Compared with the monopoly union model, we can identify two main effects of wage bargaining. First, the equilibrium wage is lower, which implies that labour demand elasticity is lower in equilibrium. From our previous analysis, we know that this reduces the likelihood that a labour-saving innovation increases labour demand. All else equal, this leads to an increase in $\theta^{*}$. But all else is not equal. Since the bargained wage is below the utility-maximising level, the term in square brackets in (23) is now positive. Consequently, a labour demand reduction can be compensated, in terms of union utility, by a wage increase. From the figure it seems that, when trade costs are zero, these two effects exactly cancel, leaving $\theta^{*}$ invariant to changes in relative bargaining strength. This result can also be confirmed analytically. ${ }^{37}$ However, for positive trade costs, the results indicate that the first effect dominates, implying that less union power over wage setting increases union resistance towards technological change.

Our previous results regarding the effects of globalisation on unions' technology opposition are also largely confirmed under wage bargaining. Trade cost reductions-in a large majority of the cases-still lead to an increase in $\theta^{*}$. The only exceptions are some combinations of very high levels of $\alpha$ and relatively large trade costs. ${ }^{38}$ However, one can

\footnotetext{
$\overline{37}$ If $t=0$, the Nash product can be expressed as $N=K\left[(w-\bar{w})^{\frac{\theta(1-\alpha)}{1+\alpha}}\left(\frac{q_{11}+q_{12}}{\phi_{1}}\right)\right]^{1+\alpha}$ where $K:=\frac{\phi_{1}^{2 \alpha}}{\left(s_{1}+s_{2}\right)^{\alpha}}$. Thus, the outcome of wage bargaining is the wage that would have been chosen by a monopoly union with relative wage orientation $\frac{\theta(1-\alpha)}{1+\alpha}$. It is straightforward to show that the corresponding value of $\theta^{*}$ is given by (17) for $t=0$. ${ }^{38}$ In Fig. 1, the plots for lower $\alpha$ are made for a narrower range of $t$ than for higher $\alpha$. This is because wages are higher when $\alpha$ is lower, and consequently, there are exports for a smaller range of trade costs.
} 
readily argue that these cases are less relevant in our context, since unions with very low wage bargaining power are unlikely to be able to prevent or delay the adoption of laboursaving innovations.

\section{Concluding remarks}

Globalisation can make technology opposition from unions more likely. Increased international integration is often seen as a force that drive economies towards efficiency and modernisation, but we have here pinpointed an effect that works in the opposite direction.

If unions sabotage technology adoption, this should be traceable in the many empirical studies on unions, $\mathrm{R} \& \mathrm{D}$, technology adoption, productivity, and the like. Menezes-Filho and Van Reenen (2003) summarise this body of work as follows: "North American results find consistently strong and negative impacts of unions on R\&D. By contrast, European studies (mainly in the UK) generally do not uncover negative effects of unions on R\&D. There is no consensus of the effects of unions on our other main measures: technological diffusion, innovation or productivity growth even in the North American studies. These cross-country differences in the R\&D impact of unions could represent either unsolved econometrics problems or genuine institutional differences between nations in union attitudes and ability to bargain. We suspect the latter is the main reason."

Unions hurt technology adoption in some circumstances and not in others. Theoretical studies like this one hopefully can help pinpoint when what happens, to the aid both of empirical studies and of policy. One should be careful to draw strong policy conclusions from a model of any one specified institutional set-up. This said, the central problem is-as in many other models of trade unionism-that the union has too much power over certain decision variables relative to others. Here, this means too much power over technology and wages relative to employment decisions. This can in general be solved either by increasing union power over some variables, or decreasing union power over others. A nationwide corporativist union might take the long-term consequences for most of the population into account, so that the outcome resembles that achieved under efficient bargaining. Taking away a union's power to sabotage technology would of course also eliminate the problem that globalisation fosters technology opposition.

Given the assumed structure-a strong union in an oligopolist firm that does not take into account the long-term effect of its own actions on the wider economy-it is actually beneficial for technology adoption that the union is wage-oriented rather than employment-oriented. A wage-oriented union could be seen as a union where the preferences of the 'insiders' in the union dominate over the 'outsiders' with less secure jobs. Job protection that increases with seniority and other measures that strengthen insider power will here in fact have the surprising side-effect of making the union more prone to accept technological change. Such changes typically increases the wages of insiders-job losses will have to be carried by the marginal 'outsiders', which is of no concern to an insider dominated union. 


\section{Acknowledgements}

We thank Torben M. Andresen, Peter Neary, and participants at a 2004 University of Aarhus conference on Globalization and labour market and welfare policies, and at the 2004 Royal Economic Society Conference in Swansea for helpful comments and suggestions.

\section{References}

Acemoglu, D., 2002. Technical change, inequality, and the labor market. Journal of Economic Literature 40, $7-72$.

Acemoglu, D., Aghion, P., Violante, G.L., 2001. Deunionization, technical change and inequality. CarnegieRochester Conference Series on Public Policy 55, 229-264.

Agell, J., Lommerud, K.E., 1993. Egalitarianism and growth. Scandinavian Journal of Economics 95, 559-579.

Andersen, T.M., Sørensen, A., 2003. International product market integration, rents and wage formation. CEPR Discussion Paper 3995.

Brander, J.A., Krugman, P.R., 1983. A reciprocal dumping model of international trade. Journal of International Economics 15, 313-321.

Brander, J.A., Spencer, B., 1988. Unionized oligopoly and international trade policy. Journal of International Economics 24, 217-234.

Brezis, E.S., Krugman, P.R., Tsiddon, D., 1993. Leapfrogging in international competition: a theory of cycles in national technological leadership. American Economic Review 83, 1211-1219.

De Fraja, G., 1993. Staggered vs. synchronized wage-setting in oligopoly. European Economic Review 37, $1507-1522$.

Desmet, K., 2002. A simple dynamic model of uneven development and overtaking. Economic Journal 112 , 894-918.

Dowrick, S., 1989. Union-oligopoly bargaining. Economic Journal 99, 1123-1142.

Dowrick, S., Spencer, B.J., 1994. Union attitudes to labor-saving innovation: when are unions luddites? Journal of Labor Economics 12, 316-344.

Duvall, F.O., 1969. Popular Disturbances and Public Order in Regency England. Oxford University Press, London.

Fudenberg, D., Gilbert, R., Stiglitz, J.E., Tirole, J., 1983. Preemption, leapfrogging, and competition in patent races. European Economic Review 22, 3-31.

Greenhouse, S., 2002. Major issue said resolved in mediation over docks. The New York Times (November 1, 2002).

Grout, P.A., 1983. Investment and wages in the absence of binding contracts: a Nash bargaining approach. Econometrica 52, 449-460.

Gürtzgen, N., 2002. Trade liberalization and union wages in a differentiated Bertrand duopoly. Open Economies Review 13, 133-151.

Gust, C., Marquez, J., 2004. International comparisons of productivity growth: the role of information technology and regulatory practices. Labour Economics 11, 33-58.

Haaland, J.I., Wooton, I., 2003. Domestic labour markets and foreign direct investment. CEPR Discussion Paper 3989.

Jørgensen, C., Navrbjerg, S.E., 2001. The involvement of employees and collective bargaining in company restructuring. European Industrial Relations Observatory Online. Available at www.eiro.eurofound.eu.int.

Lansbury, R., Lee, B.-H., Woo, S., 2002. Technology, human resources and international competitiveness in the Korean auto industry. University of Sydney, manuscript.

Lommerud, K.E., Meland, F., Sørgard, L., 2003. Unionised oligopoly, trade liberalisation and location choice. Economic Journal 113, 782-801.

Lommerud, K.E., Straume, O.R., Sørgard, L., 2005. Downstream merger with upstream market power. European Economic Review 49, 717-743. 
Lommerud, K.E., Straume, O.R., Sørgard, L., in press. National versus international mergers in unionised oligopoly. RAND Journal of Economics.

Manning, A., 1987. An integration of trade union models in a sequential bargaining framework. Economic Journal 97, $121-139$.

McAlinden, S.B., 1997. Issues in Big Three-UAW local plant negotiations: heavy weather ahead-talks between United Automobile Workers and major carmakers. Automotive Manufacturing and Production (August, 1997. http://www.findarticles.com/p/articles/mi_m0FWH/is_n8_v109/ai_20855363).

Meland, F., 2002. Unions and market integration in contests. Public Choice 112, 293-304.

Menezes-Filho, N., Van Reenen, J., 2003. Unions and innovation: a survey of the theory and empirical evidence. CEPR Discussion Paper 3792.

Moene, K.O., Wallerstein, M., 1997. Pay inequality. Journal of Labor Economics 15, 403-430.

Mowatt, S., Cox, H., 2001. From knowledge providers to knowledge seekers: chapters in the history of narrowinterest magazine print publishing. Paper presented at the European Business History Association Conference, August 2001, Oslo.

Munch, J.R., Skaksen, J.R., 2002. Product market integration and wages in unionized countries. Scandinavian Journal of Economics 104, 289-299.

Naylor, R., 1998. International trade and economic integration when labour markets are generally unionised. European Economic Review 42, 1251-1267.

Naylor, R., 1999. Union wage strategies and international trade. Economic Journal 109, 102-125.

Neary, J.P., 2002. Foreign competition and wage inequality. Review of International Economics 10, 680-693.

Neary, J.P., 2003. Globalisation and market structure. Journal of the European Economic Association 1, 245 - 271.

Piperakis, A.S., Hine, R.C., Wright, P.W., 2003. Market size and economic integration when labor markets are unionized. Review of International Economics 11, 483-494.

Reinganum, J., 1983. Uncertain innovation and the persistence of monopoly. American Economic Review 73, 740-748.

Staiger, R., 1988. Organized labor and the scope of international specialization. Journal of Political Economy 96 , $1022-1047$.

Straume, O.R., 2002. Union collusion and intra-industry trade. International Journal of Industrial Organization 20, 631-652.

Straume, O.R., 2003. International mergers and trade liberalisation: implications for unionised labour. International Journal of Industrial Organization 21, 717-735.

Ulph, A., Ulph, D., 2001. Strategic innovation with complete and incomplete labor market contracts. Scandinavian Journal of Economics 103, 265-282. 